\title{
The Study on Flood Prevention Policy Implementation in Jakarta According to Van Metter and Van Horn's Model
}

\author{
Himsar Silaban \\ Faculty of Social and Political Sciences \\ Universitas Prof Dr Moestopo (Beragama), Jakarta, Indonesia \\ himsarsilaban53@gmail.com
}

\begin{abstract}
This study presents an implementation of flood prevention policy in Jakarta, Indonesia. It is based on the implementation model of Van Metter and Van Horn's public policy. This study uses qualitative approach. The data were collected using literature study, document study, and field observation. The data analysis uses descriptive analysis method. The conclusions of this research are: The implementation of flood prevention policy in Jokowi-Ahok administration is a continuation from the implementation of flood prevention policy in the previous administration. The continuation of policy implementation in Jokowi-Ahok administration seems to be more prominent because Jokowi-Ahok set their first-year development policy focused on the efforts to overcome some prolonged development problems which are very urgent to be handled, such as flood, puddle, tidal flood, slum areas, and municipal infrastructure. The policy standard and purpose of flood prevention in Jokowi-Ahok administration can be considered quite optimal and comprehensive. Policy resources which include apparatus, facilities and infrastructure, and regulations are sufficiently optimal although there is a shortage in financing resources. Inter-organizational Communication, including horizontal communication, has been performed by Jokowi to variety of groups who have interests in flood prevention and flood victims. In addition, the characteristics of policy implementation agencies for flood prevention are the characteristics of Regional Working Unit (SKPD) formed from the distribution of government authority and the commentary of duties and functions of SKPD. Economic, social, and political conditions related to flood prevention influence the implementation of flood prevention policy in Jakarta because almost all of economic actors and economic activities, as well as almost social activities, politicians, and political activities had interests in flood prevention and in handling the impacts of flood in the capital. The disposition of implementers in flood prevention policy implementation, which influence the performance of flood prevention policy, can actually be arranged, directed, and controlled by Jakarta Provincial Government. The anticipation is performed by implementing the function of inherent supervisory, functional supervision, and community supervision.
\end{abstract}

Keywords: Flood prevention; Policy implementation; Van Metter and Van Horn's model; Jakarta.

\section{Introduction}

The area of Jakarta Capital City is lowland with an average height of seven meters above sea level. However, about 40 percent of Jakarta region is plain land surface between 1 to 1.5 meters below sea level. Based on its location, Jakarta is included as a delta city that is a city located at the estuary. Delta cities are generally located below sea level, and quite vulnerable to climate change. Delta city of Jakarta is channeled by 13 river streams affected by tidal water. Thirteen rivers and two canals flowing through Jakarta are largely tipped in West Java and emptied into Jakarta Bay. These thirteen rivers 
are Kali Mookervart, Kali Angke, Kali Pesanggrahan, Kali Grogol, Kali Krukut, Kali Baru Barat, Kali Ciliwung, Kali Cipinang, Kali Sunter, Kali Baru Timur, Kali Buaran, Kali Jati Kramat, and Kali Cakung. While the two major canals are the West and East Flood Canals. The existence of Manggarai Water Gate and the West Flood Canal is the evidence that the efforts to tackle the flooding problem in Jakarta have been done since the Dutch colonial era [1].

Floods in Jakarta are closely related to many factors such as physical development within the upstream catchment that is less well-organized, increasing urbanization, economic improvement, and global climate change. Flood in this city is actually not a new problem. From the very start, the Dutch colonial government had made the flood and water management of Jakarta an issue. Just two years after Batavia was built completed with a system of canals, in 1621, the city was experiencing flood. This is the first record in the history of the Dutch East Indies, where the main defense post of VOC in East Asia was hit by devastating floods [2]. Moreover, small floods occurred almost every year in a suburban area when the Batavia area had been widened to Glodok, Pejambon, Kali Besar, Kampung Gunung Sahari and Tambora. It is recorded that vast flood occurred in 1654, 1872,1909 and 1918 [2].

Vast floods in 1918 made almost the entire city flooded. It is reported that at that time, the water level had reached as high as human breast. One of the flood mitigation efforts undertaken by the colonial government after the great flood in 1918 was to build a water channel called the West Flood Canal in 1922. Construction of the West Flood Canal is the idea of an expert on water management, Herman van Breen. This channel was especially built to protect the city from flood, yet not to protect other areas. The length of the West Flood Canal was $17.5 \mathrm{~km}$ and at that time the canal was relatively excellent for being able to regulate the water flowing to the city of Batavia, and to accommodate water from Kali Ciliwung, Kali Cideng, Kali Krukut and Kali Grogol. At that time, the total population was relatively small; in 1930 it is recorded that Batavian population was only amounted to 811,000 people. The population pressure on the natural environment of Jakarta was not as big as now that Herman van Breen managed to easily protect the city from flood [2].

Another study, focusing on the impact of climate change in Southeast Asia and ranking the vulnerability of countries in Southeast Asia to climate change, finds some interesting facts about Jakarta. Of 530 municipalities in the seven countries studied, namely, Indonesia, Thailand, Cambodia, Laos, Vietnam, Malaysia and the Philippines, five administration areas in Jakarta are in the top 10 cities most vulnerable to climate change. Moreover, from the top 10 cities, three areas of Jakarta are occupied in the three highest rank, consisting of Central Jakarta in the first place, followed by North Jakarta and West Jakarta in the second position and in the third position. Meanwhile, East Jakarta is included in the fifth and South Jakarta in the eight ranks. Kepulauan Seribu District Administration is not included in the region vulnerable to climate change. Ten areas of the city vulnerable to climate change in Southeast Asia are the Central Jakarta; North Jakarta; West Jakarta; Mandol Kiri (Cambodia); East Jakarta; Rotano Kiri (Cambodia); National Capital Region (Philippines); South Jakarta; Bandung (West Java); and Surabaya (East Java) [3]. The study conducted by the Economy and Environmental Program for Southeast Asia (EEPSEA) creates a Climate Hazard Index constructed based on the following factors: cyclones, flood, and drought between 1980-2000, vulnerability to landslides, and the increase of sea water. EEPSEA study finds that the population density is one of the important factors in determining climate change and how a region can anticipate and adapt to climate change [3].

Almost all attempts have been made to prevent flood in Jakarta. However, as the efforts made, until now the problem of floods in Jakarta is still not solved completely. Referring to the efforts that have been done, is being done, and will be done by the Government of Jakarta with related parties in various sectors and levels, the interesting question to be answered is "How is the concept and implementation of flood prevention in 
Jakarta?" Such question becomes interesting because there are plenty resources used to address the problem of flood, many parties associated with the response to the flood problem, and so many factors that affect flood in Jakarta. Therefore, in-depth study of the concept and implementation of flood prevention in Jakarta become an unusually attractive issue to be put forward.

The rest of this paper is organized as follow: Section 2 discusses proposed methods and model of analysis. Section 3 discusses Methods of Study and Model of Analysis. Section 4 presents Analysis of Flood Prevention Policy Implementation in Jakarta. Finally, conclusion and recommendation are given in Section 5.

\section{Methods of Study and Model of Analysis}

This section discusses proposed methods and model of analysis.

\subsection{Methods of Study}

The description in the previous section shows how the issue of flood prevention in Jakarta has become a strategic issue for the local government, other stakeholders and affected parties, especially the community. Understanding how the prevention effort that has been done and will be done is associated with the flood issue that is inseparable from the role of local government as a driving force and initiator of policy implementation [4]. The arrangement and the method of government policy implemented becomes important to analyze, given that its position is as a frame of reference as well as an implementation model directly related to the technical implementation [5]. Thus, this study is then undertaken on a basic question, how is the implementation of flood prevention policy in Jakarta on Jokowi-Ahok period viewed by using the framework analysis of the implementation of policy according to Van Meter and Van Horn. Policy implementation model of van Meter and Van Horn will take this analysis to some aspects of policy standards and objectives; policy resources; communication activities between organizations; characteristics of the implementing agencies; economic, social and political conditions; and implementer disposition.

The study is then intended to analyze those policy standards and objectives; policy resources; communication activities between organizations; characteristics of the implementing agencies; economic, social and political conditions; and implementer disposition in the implementation of flood prevention policy in Jakarta, according to the model of Van Meter and Van Horn's policy implementation. This aims to analyze the performance of policy implementation and to establish a policy recommendation related to the flood prevention in Jakarta intended for the decision makers and other stakeholders. The methodology used is a qualitative research approach. Data were collected using literature study, document study, and location survey. Data were analyzed using descriptive analysis method.

\subsection{Analysis Model}

The achievement of the policy implementation is determined by the implementation model capable of ensuring the problem complexity to be solved through specific policies to be implemented [6]. There are three models of policy implementation considered easy to be adopted as an analytical tool that can be used in the process of public policy implementation. According to Wahab [7], these three models are classified into: (1) Hoogwood \& Gunn's Top-Down Approach; (2) Van Meter and Van Horn's Model of the Policy Implementation Process; and (3) Mazmanian \& Sabatier's Framework for Implementation Analysis [7].

Model of policy implementation process according to Van Meter and Van Horn emphasizes the characteristics and content of policy connecting the policy and its 
performance [8]. Furthermore, this implementation puts emphasis on procedures, prioritizing change, control and compliance action. Policy implementation can be said successful when the desired difference in the execution is relatively small, while the compliance with the program's objectives in the field is relatively high. This variable is in the form of the measurement of the policy objectives, characteristics/properties of the implementing agencies, communication between the organizations and implementation of activities, implementers' attitudes, and environmental economic, social and political conditions [7].

On the theoretical basis of Van Meter and Van Horn's model of public policy implementation which indicates six variables related to the performance of policy, namely: Policy Standards and Objectives; Policy Resources; Inter-organizational Communication and Enforcement Activities; the Characteristic of the Implementing Agencies; Economic, Social and Political Conditions; and the Disposition of Implementers. A study concept is designed, consisting of (1) the review of policy standards and flood prevention purposes; (2) study of resources for flood prevention policy; (3) study of inter-organizational communication activities in flood prevention; (4) study of the characteristics of implementing agency of flood prevention policy; (5) study of the economic, social and political conditions related to the implementation of flood prevention policy; (6) study of the disposition of implementer in the implementation of flood prevention policy [8].

\section{The Direction of Public Policy and Priority Program}

Since 2007, Jakarta Provincial Government has drawn up a work plan to handle the flood in Jakarta. One of the programs is the construction of the East Flood Canal, which reduces flooding in the East and North Jakarta that includes approximately a quarter of the total area of Jakarta. By the existence of East Flood Canal, the possibility of flooding in these regions will be relatively small. Other activity also being executed is dredging rivers and waterways. When the great flood occurred in 2007, there were 78 points of puddles that hampered the routine life of Jakarta citizens. By the flood control program implemented since 2007, 16 of the puddles had gone and targeted by 2010, 40 more would also be gone [2].

East Flood Canal was built in 2003 and began to be used in January 2010. East Flood Canal having a length of $23.5 \mathrm{~km}$ and depth of 4 to 7 meters stretches from Cipinang in East Jakarta to Marunda in North Jakarta. East Flood Canal also referred to as a collector channel or container cuts five rivers: Cipinang, Sunter Buaran, Jati, Kramat, and Cakung. The width of the East Flood Canal is not the same from upstream to downstream; in the upstream, it reaches $100 \mathrm{~m}$ and $200 \mathrm{~m}$ in the downstream and $300 \mathrm{~m}$ planned for a marina in the area of Rorotan (Ujung Menteng). East Flood Canal had actually been planned since the era of the Dutch colonial government but it never came true. In 1973, there was a study by a Dutch consultant who advised the East Flood Canal to be connected with the West Flood Canal, so it would form letter U. Now, the East Flood Canal is already functioning and the West Flood Canal has been more effective in controlling the flow of water from upstream areas. By the completion of the East Flood Canal construction, flood in eastern and northern Jakarta, which account for about a quarter of the city, has not been as severe as in previous years [2].

Planning on the efforts to control flood in Jakarta is contained in the draft of the Medium Term Development Plan (RPJMD) of Jakarta Year 2013-2017 [1]. Direction of the policy related to flood mitigation in Jakarta includes: first, the Direction of First Year Development Policy (2013): the direction of first year development policy focused on efforts to overcome various enduring and urgent development problems to be addressed, such as: flood, inundation, tidal flood, transportation, slums, and other urban infrastructure. Second, the Direction of Second Year Development Policy (2014): the 
direction of development policy is a continuation of the first year implementation of Jakarta RPJMD 2013-2017. The management of urgent development problems such as flood, transportation, slums, and other urban infrastructures continues to be implemented consistently to ensure a comprehensive solution to these problems. Third, the Direction of Third Year Development Policy (2015): regional development policy puts more emphasis on result orientation in the field based on the efforts done in previous years. The management of urgent development problems such as flood, transportation, slums and other urban infrastructure must show real results in the field that can be experienced by the society as well as the substantial progress in solving the enduring problems. Fourth, the Direction of Fourth Year Development Policy (2016): synergy among policies, programs and policies across fields is performed in order to make Jakarta as a wellorganized modern city. Besides continuously implement the efforts for tackling the enduring problems (flood, congestion, and urban infrastructure), good public service, governance and local culture development, the direction of urban development policy prioritizes the development of strategic areas that have economic potential to be integrally developed involving stakeholders.

From the description of development policy direction presented, it is known that flood prevention efforts become the focus of the efforts in addressing development problems considered to be chronic and urgent to be addressed, including the flood, inundation, tidal flood. The focus of these efforts continues until the end of the year of Jakarta RPJMD Year 2013-2017 [1].

Although the formulation of the policy is clear and the flood prevention program has been set, it does not mean that the efforts to control flood in Jakarta are absolutely effective. It is not easy to implement flood prevention policy involving many parties, using a variety of resources and being influenced by many factors. This is because there are plenty factors related to the flood problem, and this problem is actually enduring and very complex. Moreover, there are a number of obstacles difficult to overcome. In this context, the study of flood prevention policy implementation in Jakarta becomes a very interesting issue to put forward.

Public policy is essentially a development orientation selected with targets along with performance indicators and best programs in each field. Thus, public policy and excellent programs delivered in RPJMD are the priority, while the general policies and programs related to the implementation of the Minimum Service Standards (SPM) and government operational are outlined in the Strategic Plan (Renstra), and Regional Working Unit (SKPD). However, in order that the foundation of the implementation creates an unbroken bond between RPJMD and SKPD strategic plan, the programs related to the implementation of SPM as well as government operational are outlined in the Regional Development Program completed with program achievement targets for five (5) years.

\subsection{Development Public Policy}

The public policy of Jakarta development is directed to (a) implement competitive programs which are the priority programs in the regional development for 5 years in the framework of overcoming the existing problems; (b) implement other regional priority programs in accordance with the governmental affairs that should be performed; (c) implement programs considered to function as the fulfillment of minimum and operational service standards; (d) thoroughly accommodate the development programs obtained from the aspirations of the society in Musrenbang (Development Planning Meeting); (e) prioritize programs that support economic growth, increase employment and reduce poverty; (f) implement binding programs as well as to support the achievement of national development targets (Pro-Poor, Pro-Job, Pro-Growth, Pro-Environment, MDG's and MP3EI), compliance of laws and regulations (the education budget more than 20 percent), to control the central government programs, as well as to control programs 
funded by International Financial Institutions; (g) increase the level of public services from the level of sub-district, district, regency/city, to province [1].

\subsection{Regional Development Priority Programs}

The featured programs as a development priority are the strategic elaboration of the development vision and mission of Jakarta. Broadly speaking, to implement the vision and mission, the excellent programs are arranged grouped based on the strategic issues addressed [1]. The first mission includes the City Space Utilization Control Issues including, (a) Spatial Planning Program; (b) Space Utilization Program; (c) Building Supervision and Control Program; (d) Community Participation Enhancement in Spatial Planning Program; (e) Building Organizer Community Empowerment Program; (f) Spatial Service Improvement Program; (g) Spatial Information System Development Program. Economic Inequality Reduction and Employment Opportunity Extent Issues include: (a) Product Distribution Network Setup Program; (b) Domestic Trade Service Improvement Program; (c) Facilities and Infrastructure Improvement for Cooperatives and SMEs Program; (d) Cooperative Institutional Development Program; (e) Revolving Fund Provision and Cooperatives and SMEs Partnership Program; (f) SMEs Empowerment Program; (g) Food Security, Access Control, Price, Promotion and Distribution/Marketing Program; (h) Food Crop and Horticulture Improvement, Quality Control and Food Safety Program; (i) Fishery Product Improvement, Quality Control, and Food Safety Program; (j) Animal Product Improvement, Quality Control, and Food Safety Program; (k) Protection of Labor and Social Security Program; (l) Training Center System and Supporting Facilities Strengthening Program; (m) Competency Enhancement and Labor Productivity Program. Jakarta Energy an Telematics Development Issues include (a) Information and Communications Technology Utilization Optimizing Program; (b) ICT Software and Hardware Utilization Optimizing Program; (c) Promotion and Development Program of Energy and Mineral Resources Program.

The second mission includes the Transportation System Development Issues consisting of (a) Street-based Public Transportation Development Program; (b) Rail-based Mass Transportation Development Program; (c) Water Transport Development Program; (d) Traffic and Transport Control Program; (e) Traffic and Transport Safety Development Program; (f) Transportation Facilities and Infrastructure Development Program; (g) Sustainable Transport Development Program; (h) Roads and Bridges Development/ Improvement Program. Flood, Tidal Flood, and Puddles Anticipation Issues include (a) Flood Control Infrastructure Development Program; (b) Drainage System Development Program; (c) Public Works Facilities and Infrastructure Development Program; (d) Development, Management, and Conservation of Rivers, Lakes and Other Water Resources Program; (e) Flood Control and Drainage Maintenance Infrastructure Program. Issues of Environmental Protection and Management include (a) Wastewater Management Performance Improvement Program; (b) Clean Water Provision and Supply Program; (c) Waste Management Performance Improvement Program; (d) Reduction of Waste in Source Program; (e) Pollution and Environment Destruction Control Program; (f) Mitigation and Adaptation to Climate Change Program; (g) Public Participation in Environmental Management Improvement Program; (h) Disaster Risk Reduction and Predisaster Preparedness Program; (i) Structure, Infrastructure and Equipment of Fire Extinction and Rescue Development Program.

The third mission related to Urban Housing and Settlements Environmental Quality Improvement Issues include, (a) Public Housing Provision Program; (b) Public Housing Facilities and Infrastructure Development Program; (c) Public Housing Resident Candidates Preparation Program; (d) Housing Development Policy Program; (e) Handover Coordination of Apartments Built by the State Budget; (f) Quality Improvement and Village Improvement Program; (g) Community Participation 
Empowerment and Mobilization in Park and Cemetery Development Program; (h) Agricultural and Forestry Green Open Spatial Improvement Program; (i) Quantity Improvement of Green Open Space (RTH) of Parks and Cemetery Program; and (j) RTH and Cemetery Management Program

The fourth mission of Multicultural Development Issues include (a) Culture Protection, Development and Utilization Program; (b) Culture Promotion and Information Development Program; (c) Culture Facilities and Infrastructure Improvement Program; (d) Cultural Actors and Institutional Improvement Program; (e) Maintenance and Development of Local Government Buildings Program; (f) Information Provision of Housing, Settlement and Local Government Building Program; (g) Culture Promotion and Information Development Program; (h) Cultural Actors and Institutional Improvement Program; (i) Conflict Prevention and Control Program; (j) Development of National Awareness; (k) Institutional Relations Strengthening; (l) Improvement of the Community Role in the Field of Public Order, Peace and Public Protection Program; (m) Political Education for Society Program; (n) Sports and Youth Infrastructure Improvement Program. Education Quality Improvement Issues include, (a) Twelve Years Compulsory Education; (b) Education Infrastructure Improvement Program; and (c) Education Quality Improvement Program. Quality of Health Development Issues include, (a) Regional Health Care Insurance Program; (b) Health Facilities and Infrastructure Improvement Program; and (c) Birth Control Program.

While the fifth mission is associated with the Issues of Increasing the Capacity of the Apparatus include (a) Institutional Arrangement, Management and Apparatuses Resource Program; (b) Apparatus Resource Management System Improvement Program; (c) Apparatus Capacity Building Program; and (d) Discipline and Performance Improvement of Apparatuses Program. Public service improvement issues include (a) Management, Development and Utilization of Population and Civil Registration Data Program; (b) Development and Utilization of Potential and Source of Social Welfare (PSKS) Program; (c) Implementation of Services and Goods Procurement Electronically Program; (d) Optimization of Information and Communication Technology Utilization Program; (e) Integrated Information System Improvement Program; (f) Local Tax Information and Technology System Program; (g) Enterprises Performance Improvement Program; (h) Planning Management and Development Program; (i) Public Complaints Management Program (Case/Special); (j) Communication, Data and Public Information Program; (k) Sub-district Government Capacity Building Program; (l) District Government Capacity Building Program; (m) Public Service Improvement Program (Joint Technical Program); (n) Education and Training Program; (o) Investment Improvement Program; (p) City/ Regency Planning and Management Program; and (q) Optimization of ICT Software and Hardware Utilization Program.

In addition to the five missions described, Jakarta Provincial Government is also implementing priority programs in cooperation with local governments around, programmed in the form of Jabodetabek Cooperation. This is a kind of cooperation of Jakarta Province with Bodetabek (Bogor, Depok, Tangerang, Bekasi) areas carried out with (a) Jabodetabek Spatial Harmonization Program; (b) Integrated Jabodetabek Busway Service Program; (c) Jabodetabek Flood Prevention Program; (d) Jabodetabek Waste Management Program; (e) Jabodetabek Water Supply Program; (f) Jabodetabek Watershed Reforestation Program; and (g) Jabodetabek Industry and Trade Development Program.

Other priority programs are related to the Role of Jakarta as the Capital of the State. The role of Jakarta as the capital carried out with the programs as follows: (a) Capital Funding Coordination Program; (b) Role Improvement of the Governor of Jakarta Program; and (c) Inter-regional Cooperation Improvement Program.

From the description of policy direction and priority program, it is known that policies of Jakarta Local Government on Flood, Tidal Flood, and Puddles Anticipation Issues 
include (a) Flood Control Infrastructure Development Program; (b) Drainage System Development Program; (c) Public Works Facilities and Infrastructure Development Program; (d) Development, Management, and Conservation of Rivers, Lakes and Other Water Resources Program; (e) Flood Control and Drainage Maintenance Infrastructure Program. The other issues related to flood prevention policy are the Issues of Environmental Protection and Management that include (a) Wastewater Management Performance Improvement Program; (b) Clean Water Provision and Supply Program; (c) Waste Management Performance Improvement Program; (d) Reduction of Waste in Source Program; (e) Pollution and Environment Destruction Control Program; (f) Mitigation and Adaptation to Climate Change Program; (g) Public Participation in Environmental Management Improvement Program; (h) Disaster Risk Reduction and Predisaster Preparedness Program. Flood prevention policies concerning the second issues are also related to Jabodetabek cooperation policy covering flood prevention programs; Jabodetabek Flood Prevention Program, Jabodetabek Waste Management Program, Jabodetabek Water Supply Program, and Jabodetabek Watershed Reforestation Program.

\section{Analysis of Flood Prevention Policy Implementation in Jakarta}

In accordance with the implementation model of Van Metter and Van Horn's public policy, a study on the implementation of flood prevention policies in Jakarta refers to six main factors, namely: the policy standard, policy resources, communication among actors, the characteristics of the implementer agency, social, economic and political conditions, as well as the disposition of implementer related to flood prevention policy.

\subsection{Policy Standards and Purposes}

According to Van Meter and Van Horn [8], identification of performance indicators is an important step in the analysis. Basically, the performance indicators assess the extent to which those policies and objectives are realized; the complex standards and objectives that elaborate the entire goals of policy decisions. They move beyond generalization of legislative documents to provide more specific standards for assessing program performance.

Conceptually, policy standards and objectives of flood prevention in Jakarta are identified from the formulation of policy direction and priority programs of flood prevention consisting of Flood, Tidal Flood, and Puddles Anticipation Issues that include (1) Flood Control Infrastructure Development Program; (2) Drainage System Development Program; (3) Public Works Facilities and Infrastructure Development Program; (4) Development, Management, and Conservation of Rivers, Lakes and Other Water Resources Program; (5) Flood Control and Drainage Maintenance Infrastructure Program. These programs are included in the main programs category. The other issues related to flood prevention policy are the Issues of Environmental Protection and Management that include (1) Wastewater Management Performance Improvement Program; (2) Clean Water Provision and Supply Program; (3) Waste Management Performance Improvement Program; (4) Reduction of Waste in Source Program; (5) Pollution and Environment Destruction Control Program; (6) Mitigation and Adaptation to Climate Change Program; (7) Public Participation in Environmental Management Improvement Program; (8) Disaster Risk Reduction and Pre-disaster Preparedness Program. These programs are included into the category of supporting programs. Flood prevention policies concerning both groups of issues are also related to Jabodetabek cooperation policies which include (1) Jabodetabek Flood Prevention Program, (2) Jabodetabek Waste Management Program, (3) Jabodetabek Water Supply Program, and (4) Jabodetabek Watershed Reforestation Program. Other programs that are also positively correlated with the implementation of flood prevention policies are the programs associated with the competency improvement of apparatuses, performance 
improvement of the apparatuses and effectiveness improvement of the administrative resource management and the expansion of apartment development and transportation infrastructure. These programs are included in the category of related programs.

From the data obtained, it is known that the Featured Programs of Jakarta Government in 2013 are (1) Development of East Flood Canal (KBT), (2) Normalization of Rivers and Drainage Channels, and (3) Management of the Construction of Reservoirs, Artificial Lakes, and Embankments of Coastal Protection and Infiltration Wells. In the process of the implementation of flood prevention policies, five main programs package; eight supporting programs package; and related program packages are elaborated into activities by each SKPD and also by the parties concerned. Each activity is described with more specific goals and objectives in accordance with the performance of the budget in each fiscal year. By promoting the role of general manager (that may be played by Ahok) and the role of the manager played by each head of SKPD mainly by the SKPD functioning as the leading sector, thus, the implementation of these activities becomes more organized, focused, and integrated to achieve the goals and targets of flood prevention thoroughly.

In this context, the elaboration of Flood, Tidal Flood, and Puddles Anticipation Issues and the Issues of Environmental Protection and Management and other related issues that create the policy standards and objectives for flood prevention in Jakarta becomes more organized, purposeful, integrated, comprehensive, and sustainable. Thus, the policy standards and objectives of flood prevention in the era of Jokowi-Ahok leadership can be quite optimal and comprehensive. This policy became popular because Jokowi-Ahok highlighted the issue of flood, tidal flood, and inundation as one of the strategic issues in their leadership, organized into a planning system that is systemic in RPJMD. Therefore, the efforts to prevent flood in Jakarta are not limited only to the time of the occurrence of the floods. However, the effectiveness or success of the implementation of flood prevention various programs and activities in Jakarta is obviously very dependent on the support of policy resources.

\subsection{Policy Resources}

According Van Meter and Vanhorn [8], policy provides more than just assessment standards of the implementation of the objectives. Policy also requires the provision of resources to facilitate the administration of the policy. These resources may include funds or other incentive programs that may encourage or facilitate their effective implementations.

If the resources are administrative resources of Jakarta Government, then the resources include apparatus resources (man), financial resources (money), infrastructure resources (material), and regulation resources (method). Since the flood prevention efforts require the support of all resources, involve many parties, and use various methods, the resources of public administration are definitely not sufficient. It takes supports of more optimal and comprehensive resources, so that the implementation of those policies and achievement of the objectives of flood prevention can be optimal and achieve all targets.

By its position as the capital, Jakarta government is certainly not too difficult to mobilize to gather the resources needed to implement the policies and activities of flood prevention. In addition, the resources needed by the local government are indeed not only available in internal environments, but also in the external environments. This is because almost all parties in various sectors and levels put an interest in the success of the efforts to control flood and its impacts in Jakarta. Resources in the external environment raised and collected by the local government become effective potentials for the flood prevention, among others, economic resources, social resources, political resources, and cultural resources of the society, whether at the local, regional, national or international level. By the concept of clear and accurate policies with proper communication patterns, 
Jokowi-Ahok could certainly mobilize and gather external resources into an effective potential unit of flood prevention and its impact.

Meanwhile, personnel resources, facilities and infrastructure resources, and the regulation resources within the internal scope of Jakarta government, seem to have been working quite optimal to implement flood prevention policies and activities, but not for the case of financial resources. Although the local revenue (PAD) of Jakarta in fiscal year 2013 reached IDR 26,670.5 billion or 53.36 percent of the total budget amounted IDR $49,979.8$ billion, the limited financial resources still become one of the real challenges for Jokowi-Ahok in effecting the implementation of flood prevention policy. Therefore, given that the problem of flood in Jakarta is very complex and is influenced by the natural condition that actually beyond the control of Jakarta Government, the limited financial resources have become one of the factors that lead to the inability of thoroughly performing flood prevention program in Jakarta in one fiscal year. It needs a sustained reduction of one fiscal year to the next financial year; the sustainability of leadership in one period to another period of leadership. Therefore, the performance of flood prevention policies in five-year budget cannot guarantee the solution of flood and the impact in Jakarta. With a planning system that is sustainable, consistent and systemic, it takes a minimum of thirty-year budget to totally overcome the flood and its impact in Jakarta.

\subsection{Activity of Inter-organizations Communication}

According to Van Meter and Van Horn [8], the effective implementation of policies requires that the program standards and objectives be understood by the people responsible for achieving these objectives. Therefore, the clarity of standards and purposes, the accuracy of communication policy for the executive, and the consistency communicated through a variety of information are required. Standards and goals cannot be done unless the policy is expressed with sufficient clarity so that the implementers know what to expect from the policy. Communications within and between organizations are a complex and difficult process. In the transmission of messages in an organization, or from one organization to another, communicators are definitely distorting policies - either intentionally or unintentionally. Furthermore, if a different source and communication give inconsistent interpretation of standards and objectives, or if the same sources give conflicting interpretations over time, then the executive will find it difficult to implement the policy direction. Therefore, the prospects for effective implementation can be improved by clarity on standards and objectives stated accurately and consistently with what is being communicated.

One of the interesting things that often said and done by Jokowi is communication. Communication is of course not limited to the internal organizational communication within the city government, but includes the external communication with stakeholders in different sectors and levels. Jokowi performed horizontal communication to various parties concerned with flood prevention efforts and the parties affected by the floods. Horizontal communication is carried out by Jokowi to promote policy and foster the community potential and participation. Structural communication was done to various leaders of related government agencies. This structural communication was performed by Jokowi to get supporting resources; for example, communication with the leaders of the People's Consultative Assembly and the President.

Jakarta Governor, Joko Widodo met the Chairman of the People's Consultative Assembly (MPR), Taufik Kiemas in the morning, Monday, January 21, 2013. During the meeting, this former Mayor of Surakarta mentioned six steps that will be taken by Jakarta Government to overcome the flood in the capital. "I have conveyed the six steps to the President of Indonesia," said Jokowi in a press conference in the MPR, Jakarta, on Monday, January 21, 2013. The six steps include normalization of the river. Later, the 
central government and Jakarta government would normalize 13 rivers in Jakarta. However, the focus on that year was given to Ciliwung, Pesanggrahan, Angke and Sunter. Then he also mentioned that there would be Otista duct to the East Flood Canal. In addition, there would be a large dam in Ciawi and Cimanggis, West Java. The fourth step was making many infiltration wells from upstream to downstream. It is useful to reduce the flow of water that goes into Jakarta. Another step was the immediate manufacture of a number of water pumps in North Jakarta. "This is to reduce the pool of water in North Jakarta," he said. Then the last step prepared by Jokowi was the construction of multipurpose deep-tunnels in Jakarta. "The review is positive, so that it can be done. Hopefully it could be a breakthrough," he said. Besides consulting to Taufik Kiemas, he also asked for support from the leadership of the MPR and DPR related to the flood in Jakarta. "Whatever it is, flood is not a small matter. Starting from the central government, local governments, and the public, we must work together, hopefully these problems can be resolved one by one," he said. The Head of MPR, Taufik Kiemas, argued, the flood in Jakarta cannot be overcome by the local government itself. "At this time, we must give our hearts to work together," said Taufik [9]. Of the various horizontal and structural communication activities conducted by Jokowi, he apparently managed to carry out the organization communication functions, and also managed to convince the parties to support the implementation of flood prevention policy in Jakarta. Thus, communication activities carried out by Jokowi basically aimed for socializing, consulting, coordinating, consolidating, and at the same time synergizing resources and the involvement of stakeholders in the process of policy implementation and flood prevention activities in the capital. Thus, Jokowi understands the function and importance of communication in the process of public policy implementation, and Jokowi can actualize the implementation of the communication function effectively to mobilize policy resources.

\subsection{The Characteristics of Policy Implementing Agency}

Van Meter and Van Horn [8] explain that many factors are included in the model component. Many characteristics of administrative agency have been identified affecting the performance of the policy. Ripley et al., [10] for example, define the bureaucratic structure as people with "characteristics, norms, and a repeating pattern of relationships which have either potential or actual relationship to the function served by the policy." Similar with Ripley, et al. in [10] we can see that this component consists of two features of formal organization structuring and personnel informal attributes. Without attempting to provide an exhaustive list of these elements, the characteristics may be associated with the organization's capacity in implementing the policy, namely competence and number of the staff of an agency; hierarchical control level of sub-unit decision and process in executive agencies; political resources of an institution; the vitality of the organization; the degree of communicational "openness" within an organization; relationship between formal and informal institutions with policy-making [10].

Characteristics of the policy implementing agency in Jakarta governance is the characteristic of the regional working units (SKPD) formed by the distribution of government authority with a description of the duties and functions of SKPD. This characteristic is especially prominent in the SKPDs that become policy implementation leading sector; and SKPDs supporting the successful implementation of flood prevention policy. Besides, in general, the competence and the number of staff at each SKPD are sufficient to carry out various activities for flood prevention and handling of the floods. Moreover, the implementation of these policies is accompanied by the implementation of the supervisory function attached by the respective SKPD leaders, and functional supervision by the Regional Inspectorate. Consultation and coordination are performed among SKPDs in order to integrate and facilitate the implementation of various activities. Thus, the characteristics of the policy implementing agency of flood prevention in Jakarta 
have been formed from the structure and authority, description of the main tasks and functions, and the capacity of the apparatus on each SKPD such as the Public Works Department, Sanitation Department, Parks and Cemeteries Department, Department of Housing and the others associated with the handling of the floods.

\subsection{Economic, Social and Political Conditions}

According to Van Meter and Van Horn [8], the impact of economic, social, and political conditions on public policy has become the focus of attention of many people over the past decade. Students of Comparative Public Policy and State Politics have identified the influence of environmental variables on policy output. Although the impact of these factors on the implementation of policy decisions has received little attention, the policy may have a profound effect on the performance of the executing agencies. Van Meter and Van Horn [8] showed that for the purpose of illustration, it is proposed that consideration is given to the following questions about the economic, social, and political environments influencing jurisdictions or organizations in the implementation of policies applied. The questions are: (a) are the available economic resources in the jurisdiction of policy implementer sufficient to support the successful implementation of these policies? (b) to what extent (and how) the economic and social conditions will be affected by the implementation of the policy? (c) what is the public opinion, and how those opinions prominent as an issue associated with the policy? (d) does the elite support or oppose the implementation of the policy? (e) what kind of artisan characteristics of the implementation jurisdiction, is there any partisan opposition or support for poly-partisan? (f) to what extent the private interest groups is mobilized to support or oppose the policy?

By its position as the capital, which is the center of government and business, then automatically, its economic, social, and political environments strongly influence the implementation of flood prevention policy in Jakarta, given that the social, economic, and political aspects play significant role in the dynamics of the state and society [11]. This is because almost all economic actors and economic activities; almost all social activities; politicians and political activities can be said to be concerned with the efforts of flood prevention and the handling of the impact of floods in the capital. This means that the role of the parties, according to the position, role and potential, certainly criticize or support the implementation of flood prevention policy and the handling of its impact. How the parties criticizing or supporting the implementation of flood prevention policy and management of the impact of the floods in Jakarta appear when Jakarta is flooded. The parties from different economic environment, social environment, and political circles seem to participate in the handling process of the problem of the flood and its impact. Thus, since the position of Jakarta as the Capital of the State, and since each party also feels concerned with flood prevention efforts, the parties from different economic environment, social environment and political circles tend to support the implementation of flood prevention policy and the handling of the floods. This trend is reinforced by the communication activities conducted by Jokowi.

\subsection{Disposition of Implementer}

According to Van Meter and Van Horn [8], every component of the model will be filtered through the perceptions of implementer in jurisdictions where the policy is implemented. The elements of the implementer response can affect the ability and willingness to implement the policy, including: the implementers' understanding of the policy, direction of the response of policy implementers on the policy (reception, neutrality, rejection), and the intensity of the response. Furthermore, Van Meter and Van Horn [8] said that the dispositional direction of policy implementer towards the standards and objectives are very important as well. The policy implementer may fail in implementing policies because they reject the objectives contained in the policy. Instead, 
the widespread acceptance of policy standards and objectives on those who are responsible will increase the potential for a successful execution. At least, it can be indicated that the attitude of sharing will make the implementation easier. Van Meter and Van Horn [8] reminded that eventually the intensity of the disposition of the implementer may also affect the performance of the policy. Less intense attitude can cause a diversion of policy implementer to try to be passive and hindered from more general pattern.

The intensity of policy implementer disposition that affects performance flood prevention policy can actually be arranged, directed, and controlled by the city government. The anticipation is done by implementing inherent supervision functions, functional control, and public control. Structurally, the inherent supervisory function performed by the elements of leadership in each SKPD is tasked to implement flood prevention activities according to each duties and functions. At a certain level, Jokowi's role as Regional Head was certainly needed and it determined the successful implementation of the policies. Referring to the disadvantaging behavioral tendency problem of the policy implementer, the functional supervision conducted by the Regional Inspectorate is an inconsistency deterrent in policy implementation. Meanwhile, the public control, especially those carried out by members of the press, obviously is an effective control on the performance of the policy. Accordingly, implementer's disposition in the implementation of flood prevention policy that can reduce the intensity of the performance of the policy cannot be separated from the strong influence of the implementation of the supervisory function by various parties. This means that in the implementation of flood prevention policy in Jakarta, the behavioral tendency of apparatus that can reduce the effectiveness of the flood prevention operations is not the dominant factor and can be anticipated.

\section{Conclusion and Recommendation}

From the discussion of the study using the model of Van Metter and Van Horn's public policy implementation, the conclusions obtained are as follows:

\subsection{Conclusion}

The implementation of flood prevention policy in the era of Jokowi-Ahok leadership is a continuation of policy implementation of the flood prevention in the era of the previous leadership. The continuation of the implementation of flood prevention policy in the era of Jokowi-Ahok leadership became more prominent, because Jokowi-Ahok set the direction of development for the first year focused on efforts to overcome the various chronic and urgent problems of the development to be addressed, among others, flood, inundation, tidal flood, slums settlements, and other urban infrastructure. This policy direction is reflected on the issues of flood, tidal flood, and inundation covering Flood Prevention Infrastructure Development Program; Drainage System Development Program; Public Works Facilities and Infrastructure Improvement Program; Development, Management, Conservation of Rivers, Lakes and Other Water Resources Program; Flood Prevention Maintenance Infrastructure and Drainage Program; as well as Jabodetabek Flood Prevention Program; Jabodetabek Waste Management Program; Jabodetabek Clean Water Programs; and Jabodetabek Watershed Reforestation Program.

According to the Van Metter and Van Horn's implementation model of public policy: (1) The policy standards and objectives of flood prevention in the era of Jokowi-Ahok leadership can be quite optimal and comprehensive. This policy became popular because Jokowi-Ahok highlighted the issues of flood, tidal flood, and inundation as one of the strategic issues in leadership, and organized into a systemic planning system in RPJMD.

(2) The policy resources cover apparatuses, resources, facilities and internal regulation resources that are sufficient and optimal for implementing the policies and activities of flood prevention. However, this is not similar with financial resources. Although the 
reception of Jakarta local revenue in fiscal year 2013 reached IDR $26,670.5$ billion or 53.36 percent of the total regional budget amounted to IDR 49,979.8 billion, the limited financial resources still be one of the real challenges for Jokowi- Ahok in effecting the implementation of flood prevention policy. (3) Communication between organizations in the implementation of flood prevention policy includes communications organization in the internal environment of the local government; and external communication with stakeholders in different sectors and levels. Jokowi performed horizontal communication to various parties concerned with flood prevention efforts and the parties affected by the floods. Horizontal communication was done by Jokowi to promote and foster the potential policy and community participation. Structural communication was done to various leaders of related government agencies. This structural communication was performed by Jokowi to get supporting resources. (4) The characteristics of flood prevention policy implementing institutions are the characteristics of the regional working units (SKPD) formed by the distribution of governmental authority and a description of the duties and functions of SKPD. These characteristics are especially prominent in the leading sector of policy implementation and SKPDs that support successful implementation of flood prevention policy. Besides, in general, the competence and the numbers of staff at each SKPD are sufficient to carry out various activities for flood prevention and handling of its impacts. Moreover, the implementations of these policies are accompanied by the implementation of the supervisory function attached by their respective SKPD leaders, and functional supervision by the Regional Inspectorate. In each SKPD, consultation and coordination are performed in order to integrate and facilitate the implementation of various activities.(5) The economic, social and political conditions related to flood prevention affect the implementation of flood prevention policy in Jakarta, since almost all economic actors and economic activities; almost all social activities; politicians and political activity were concerned with the efforts of flood prevention and handling of the impact of floods in the capital. This means that the role of the parties, according the position, role, and potential, can criticize or support the implementation of flood prevention policy and the handling of the impact of floods. How the parties criticizing or supporting the implementation of flood prevention policies and management of the impact of the floods in Jakarta appear when Jakarta was flooded. (6) Implementer disposition in the implementation of flood prevention policies that affect performance of flood prevention policy can actually be arranged, directed, and controlled by the city government. The anticipation was done by carrying out inherent control functions, functional supervision, and public control. Structurally, the inherent supervisory function performed by the elements of leadership in each SKPD is tasked to implement flood prevention activities according to each duties and functions. At a certain level, Jokowi's role as Regional Head was certainly needed and it determined the successful implementation of the policies. Referring to the disadvantaging behavioral tendency problem of the policy implementer, the functional supervision conducted by the Regional Inspectorate is an inconsistency deterrent in policy implementation. Meanwhile, the public control, especially those carried out by members of the press obviously is an effective control on the performance of the policy. Accordingly, implementer disposition in the implementation of flood prevention policy that can reduce the intensity of the performance of the policy cannot be separated from the strong influence of the implementation of the supervisory function by various parties.

\subsection{Recommendation}

In order to make the efforts of flood prevention and its impact management in Jakarta more organized, more targeted, more integrated, and systemically sustainable, it is recommended that Jakarta Provincial Government draft a Master Plan for Flood Management in Fifteen Years Ahead. The Master Plan includes (1) Flood Control 
Infrastructure Development Program; (2) Drainage System Development Program; (3) Public Works Facilities and Infrastructure Development Program; (4) Development, Management, and Conservation of Rivers, Lakes and Other Water Resources Program; (5) Flood Control and Drainage Maintenance Infrastructure Program; (6) Wastewater Management Performance Improvement Program; (7) Apartment Provision Program; (8) Waste Processing Performance Improvement Program; (9) Reduction of Waste in Source Program; (10) Pollution and Environment Destruction Control Program; (11) Mitigation and Adaptation to Climate Change Program; (12) Public Participation in Environmental Management Improvement Program; (13) Disaster Risk Reduction and Pre-disaster Preparedness Program; (14) Jabodetabek Flood Prevention Program; (15) Jabodetabek Waste Management Program; (16) Jabodetabek Water Supply Program; (17) Jabodetabek Watershed Reforestation Program.

\section{Acknowledgement}

This research is supported by Universitas Prof Dr Moestopo (Beragama), Jakarta, Indonesia.

\section{References}

[1] Jakarta Provincial Government, “Jakarta Middle Term Development Plan 2013-2017”, Jakarta: Provincial Secretariat of Jakarta, (2013).

[2] T. M. Sakethi, "Mengapa Jakarta Banjir? Pengendalian Banjir Pemerintah Provinsi DKI Jakarta", Jakarta: PT. Mirah Sakethi, (2010).

[3] A. A. Yusuf and H. Francisco, "Climate change vulnerability mapping for Southeast Asia". Economy and Environment Program for Southeast Asia (EEPSEA), (2009), pp. 10-15.

[4] B. W. Head and J. Alford, "Wicked problems: implications for public policy and management", Administration \& Society, vol. 47, no. 6, (2015), pp. 711-739

[5] E. Bardach and E. M. Patashnik, "A Practical Guide for Policy Analysis: The Eightfold Path to More Effective Problem Solving”, New York: CQ press, (2015).

[6] W. N. Dunn, "Public Policy Analysis",. New York: Routledge, (2015).

[7] S. A. Wahab, "Analisis Kebijakan: Dari Formulasi ke Penyusunan Model-Model Implementasi Kebijakan Publik", Jakarta: PT. Bumi Aksara, (2005).

[8] D. S. Van Meter and C. E. Van Horn, "The policy implementation process: a conceptual framework", Administration \& Society, vol. 6, no. 4, (1975), pp. 445-488.

[9] S. Decilya, "6 Cara Jokowi Atasi Banjir Jakarta", Taken from Tempo Metro: (2011), http://www.tempo.co/read/news/2013/01/21/064455822/6-Cara-Jokowi-Atasi-Banjir-Jakarta.

[10] R. B. Ripley and G. A. Franklin, "Policy Implementation and Bureaucracy (2nd ed.)", Chicago: The Dorsey Press, (1990).

[11] J. D. Brown and S. L. Damery, "Managing flood risk in the UK: towards an integration of social and technical perspectives", Transactions of the Institute of British Geographers, vol. 24, no. 7, (2002), pp. $412-426$ 
International Journal of $u-$ and e- Service, Science and Technology Vol.10, No.4 (2017) 